\title{
Fruit flies of citrus in Nigeria: species diversity, relative abundance and spread in major producing areas
}

\author{
Vincent C. UMEH ${ }^{1 *}$, Loyd E. GARCIA ${ }^{2}$, Mark De MEYER ${ }^{3}$
}

${ }^{1}$ Natl. Hortic. Res. Inst., P.M.B. 5432, Idi-Ishin, Jericho Reservation Area, Ibadan, Nigeria

vumeha@yahoo.com

2 USDA, APHIS, PPQ, 920

Main Campus Drive, Suite 200, Raleigh, North Carolina 27606, USA

${ }^{3}$ R. Mus. Centr. Afr., Leuvensesteenweg 13, B3080, Tervuren, Belgium

* Correspondence and reprints

Received 13 June 2007 Accepted 27 August 2007

Fruits, 2008, vol. 63, p. 145-153 (c) 2008 Cirad/EDP Sciences All rights reserved DOI: $10.1051 /$ fruits:2008004 www.fruits-journal.org RESUMEN ESPAÑOL, p. 153

\section{Fruit flies of sweet oranges in Nigeria: species diversity, relative abundance} and spread in major producing areas.

Abstract - Introduction. Fruit fly attack on citrus causes economic yield losses in Nigeria. The high demand for sweet oranges in recent times necessitates the need to develop control strategies that can reduce fruit fly damage and ameliorate yield. This can be achieved by identifying the diversity, abundance and spread of major sweet orange fruit flies. Materials and methods. Surveys were conducted during the citrus fruit maturity periods of 2003 and 2006 in citrus-producing areas of Nigeria. Owners of the sampled orchards were interviewed on their cultural practices that could contribute to fruit fly abundance and spread. The fruit flies were sampled by using two types of trap; namely, the McPhail ${ }^{\circledR}$ trap with yeast hydrolysate bait and the yellow sticky trap impregnated with ammonium acetate. The traps were hung on the citrus trees at a distance of $1.8 \mathrm{~m}$ from the ground. The distance between trees was $25 \mathrm{~m}$ and the traps were replicated three times per site. Results and discussion. Fruit flies identified on citrus belonged to the genera Bactrocera, Ceratitis, Dacus and Trirhithrum. While higher fruit fly diversity was observed in Edo, Ogun and Oyo states in the rainforest ecological zone, relatively higher populations of major genera (Bactrocera and Ceratitis) were recorded in Benue and Kaduna states in the Guinea savanna ecological zone. Bactrocera species occurrence increased during the second sampling period. Some farmers' cultural practices were implicated as factors likely to have contributed to fruit fly abundance and spread. Conclusion. Fruit fly species of economic importance to citrus in Nigeria belonged to the genera Ceratitis and Bactrocera species. These genera were observed in the majority of surveyed areas.

Nigeria / Citrus / fruit-damaging insects / Tephritidae / Ceratitis / Bactrocera / Dacus umebi / identification / cultivation / traps

Les mouches des fruits des agrumes au Nigéria : diversité des espèces, abondance relative et extension dans les principales zones productrices.

Résumé - Introduction. L'attaque des agrumes par les mouches des fruits au Nigéria cause des pertes de rendement à répercussions économiques. La forte demande d'oranges douces enregistrée ces derniers temps impose de développer des stratégies de contrôle aptes à réduire les dommages imputables aux mouches des fruits et à améliorer le rendement. Cela peut être réalisé en identifiant la diversité, l'abondance et la diffusion des principales mouches des fruits des oranges douces. Matériel et méthodes. Des prospections ont été menées pendant les périodes de maturité des agrumes en 2003 et en 2006, dans des zones productrices du Nigéria. Les propriétaires des vergers échantillonnés ont été interviewés sur les pratiques culturales qui pourraient contribuer à l'accroissement des populations des mouches des fruits et à leur diffusion. Les mouches des fruits ont été collectées en utilisant deux types de piège à savoir le piège de McPhail $^{\circledR}$ avec appât d'hydrolysat de levure et le piège collant jaune imbibé d'acétate d'ammonium. Les pièges ont été accrochés sur des agrumes à $1,8 \mathrm{~m}$ de hauteur, à raison de trois pièges par site. La distance entre les arbres a été de $25 \mathrm{~m}$. Résultats et discussion. Les mouches des fruits identifiées sur agrumes ont été rattachées aux genres Bactrocera, Ceratitis, Dacus et Trirhithrum. Alors qu'une diversité plus élevée de mouches des fruits a été observée dans les états d'Edo, d'Ogun et d'Oyo en zone écologique de forêt tropicale, des populations relativement plus importantes des principaux genres (Bactrocera et Ceratitis) ont été enregistrées dans les états de Benue et de Kaduna en zone de savane guinéenne. L'occurrence d'espèces de Bactrocera a augmenté au cours de la deuxième période de prélèvement. Les pratiques culturales de certains agriculteurs se sont révélées être des facteurs probables contribuant à l'abondance et à la diffusion des mouches des fruits. Conclusion. Les espèces de mouches des fruits d'importance économique sur agrumes au Nigéria appartiennent aux espèces des genres Ceratitis et Bactrocera. Ceux-ci ont été identifiés dans la majorité des régions prospectées.

Nigéria / Citrus / insecte déprédateur des fruits / Tephritidae / Ceratitis / Bactrocera / Dacus umehi / identification / pratique culturale / piège 


\section{Introduction}

Constraints militating against the realization of maximum citrus fruit yield in Nigeria include, among others, damage by fruit flies. This group of insects belongs to the family Tephritidae. At present, some 4352 species (including subspecies) in 483 genera have been described in the world, of which many species are of economic importance [1]. There has been a lot of neglect of the fruit fly menace for a long time in Africa and, consequently, huge resources running into millions of dollars are continuously being lost. Furthermore, the list of newly introduced fruit fly species is on the increase [2] and, recently, an invasive species, Bactrocera invadens Drew, Tsurata and White was identified in parts of Africa including West Africa [3, 4]. The latter implies further increase in yield losses. The bulk of sweet oranges (the citrus type most cultivated) marketed in Nigeria are produced by smallholder farmers [5, 6]. The majority of these farmers are neither aware of ideal citrus production practices nor acquainted with efficient fruit fly control options. However, with the present export promotion drive initiated by the government of the federal republic
Figure 1.

Map of Nigeria showing the states surveyed regarding the presence of fruit flies on citrus and the observed fruit fly genera. of Nigeria, there is a concerted effort being made to improve fruit production by reducing obvious constraints.

In Africa south of the Sahara, particularly in Nigeria, little research work has been carried out on identifying and combating fruit flies of economic importance to the horticultural industry. Most research work conducted in Nigeria on fruit flies of citrus focused only on a part of the country and on Ceratitis capitata (Wied.), the most economically important species attacking sweet oranges in the past decades [7-9]. A recent minor survey revealed the presence of other economically important species (Umeh, unpublished data). Therefore, the present work is aimed at identifying fruit flies of economic importance to sweet oranges, their abundance and spread in major producing areas. The derived information will be used to develop environmentally safe and costeffective fruit fly control measures for smallholder citrus farmers.

\section{Materials and methods}

\subsection{Study sites}

The study was carried out during the citrus maturity periods of October-November 2003 and May-June 2006 in the producing areas of Anambra, Benue, Delta, Edo, Imo, Kaduna, Nasarawa, Ondo, Ogun, Oyo and Plateau states (lat. $6^{\circ}-10^{\circ} \mathrm{E}$ and long. $5^{\circ} 20^{\prime}-$ $10^{\circ} 20^{\prime} \mathrm{N}$ ) (figure 1) covering the rainforest, forest-savanna transition and Guinea savanna agro-ecological zones of Nigeria (figure 2). However, the surveyed parts of Plateau state are in the montane ecology.

Sweet orange is the major citrus type cultivated in Nigeria and was therefore chosen for this trial. The surveys were conducted in sweet orange orchards near towns and villages, as well as in homestead sweet orange stands. A minimum of 10 sweet orange stands should be available in the location for the traps to be set. Five sites were sampled in each of the 11 states and thus 55 sites in the sampled areas were covered per year (figure 1). 


\subsection{Interviews with farmers}

In 2003, farmers owning the sampled orchards or homestead sweet oranges were orally interviewed using a structured questionnaire to cover aspects of cultural practices related to fruit fly damage. These practices included the removal of dropped fruits, stage of ripeness before harvesting, and other plant species susceptible to fruit fly attack which were intercropped with sweet oranges.

\subsection{Setting of fruit fly traps}

To trap fruit flies in the orchards or the homestead stands, two types of traps were used; namely, the McPhail ${ }^{\circledR}$ trap with yeast hydrolysate bait and the yellow sticky trap (Pherocon ${ }^{\circledR}$ trap) impregnated with ammonium acetate and layered with tanglefoot ${ }^{\circledR}$ glue. The yellow sticky trap was already made ready for use by the manufacturers. The yeast hydrolysate baits were in pellets (Era ${ }^{\circledR}$ bait pellets). A measure of $36.8 \mathrm{~g}$ of the pellets was dissolved in $600 \mathrm{~mL}$ of lukewarm water $\left(45-50{ }^{\circ} \mathrm{C}\right)$ and a volume of $300 \mathrm{~mL}$ of the solution was poured into each McPhail ${ }^{\circledR}$ trap. Each of the two types of traps was hung on a separate tree randomly selected while maintaining a distance of $25 \mathrm{~m}$ between the trees. The traps were hung at a height of $1.8 \mathrm{~m}$ from the ground. Each trap was replicated three times per site, i.e., three traps of each type were used per site. The trap arrangement was a randomized complete block design.

\subsection{Collection and identification of insects}

An interval of five days was allowed between the placement of traps and recovery of trapped insects. Collected insects were stored in $70 \%$ ethanol for identification in the laboratory.

Twenty fruits randomly picked in each sampled tree were observed for fruit fly damage, usually characterized by spot discolorations due to fly entry or exit points. The damaged ones were expressed as a percentage of the total sample.

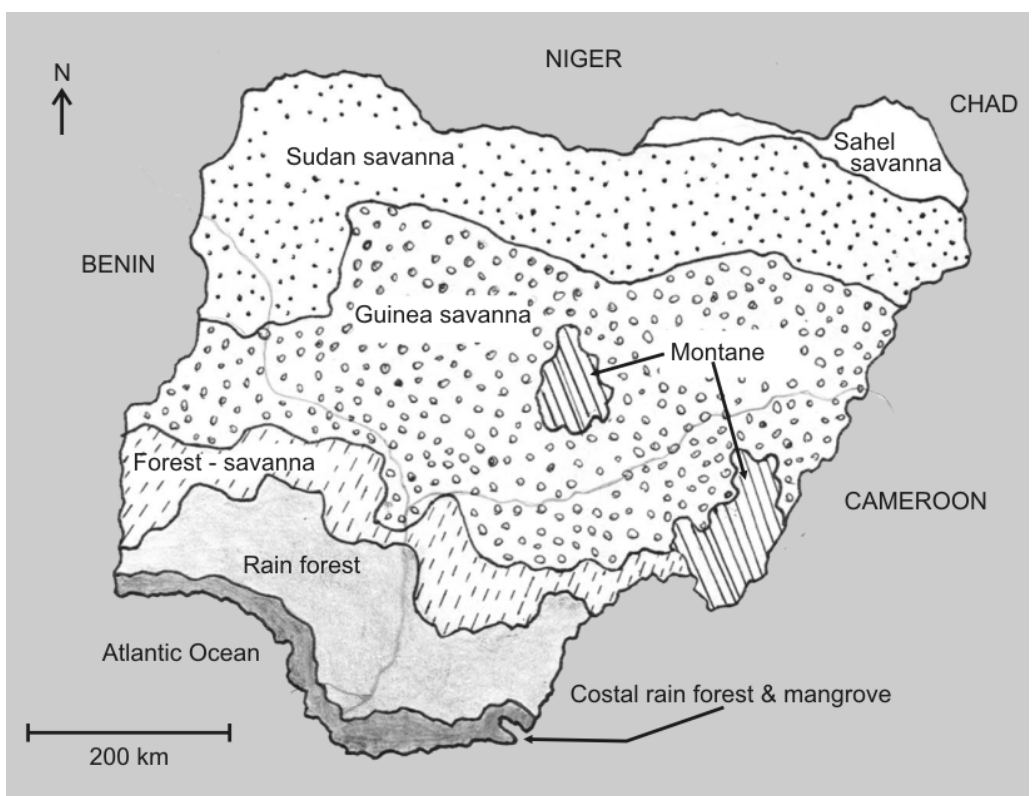

Ten attacked fruits per site were stored in paper bags and were later transferred to cages in order to raise the immature stages of fruit flies they harbored to adulthood. Each cage $[(0.4 \times 0.6 \times 0.6) \mathrm{m}]$ was covered at the sides by glass and at the base by sandcovered plywood. The emerged fruit flies and those collected from traps were identified in the laboratory at the National Horticultural Research Institute, Ibadan, Nigeria, using available keys compiled by White and Elson-Harris [10].

Fruits that dropped beneath the trees were rated 1 to 4 according to the number observed beneath each tree as follows: no fruit drop: 0; 1-10 fruits dropped: 1 ; 1120 fruits dropped: $2 ; 21-30$ fruits dropped: 3 ; > 30 fruits dropped: 4 .

Farmers' responses on the removal of dropped fruits were rated 0 to 3 as nonremoval, part-removal and total removal, respectively; while stages of ripeness before harvest were rated according to the estimated percentages of apparently ripe fruits before harvest: $<50 \%$ fruits: $1 ; 50 \%$ fruits: 2 ; $>50 \%$ to $70 \%$ fruits: 3 ; and $>70 \%$ fruits: 4 .

Unidentified samples of fruit flies caught in the traps were shipped to tephritid experts, Drs. R. Wharton, M. de Meyer and I.M. White, for confirmation.

\section{Figure 2.}

Map of Nigeria showing the different ecological zones where citrus was surveyed regarding the presence of fruit flies. 
Table I.

Species diversity of fruit fly in major citrus-producing areas of Nigeria.

\begin{tabular}{|c|c|c|c|}
\hline Identified fruit fly species & $\begin{array}{l}\text { State in which identified fruit fly } \\
\text { species were observed }\end{array}$ & $\begin{array}{l}\text { Source } \\
\text { of observed fruit fly }\end{array}$ & Agro-ecological zones \\
\hline Ceratitis capitata (Wied.) & $\begin{array}{l}\text { Anambra, Benue, Delta, Edo, } \\
\text { Nasarawa, Ogun, Ondo, Oyo }\end{array}$ & Traps, fruits & $\begin{array}{c}\text { Forest savanna, Guinea savanna, } \\
\text { rainforest }\end{array}$ \\
\hline $\begin{array}{l}\text { C. (Pardalaspis) ditissima } \\
\text { (Munro) }\end{array}$ & Edo, Delta, Imo, Kaduna, Ondo, Oyo & Traps, fruits & $\begin{array}{c}\text { Forest savanna, Guinea savanna, } \\
\text { rainforest }\end{array}$ \\
\hline $\begin{array}{l}\text { C. (Pterandrus) penicillata } \\
\text { (Bigot) }\end{array}$ & Ondo, Oyo & Traps & Forest savanna, rainforest \\
\hline Dacus bivittatus (Bigot) & $\begin{array}{c}\text { Anambra, Benue, Delta, Edo, Imo, } \\
\text { Kaduna, Nasarawa, Ondo, Oyo, } \\
\text { Plateau }\end{array}$ & Traps & $\begin{array}{c}\text { Forest savanna, Guinea savanna, } \\
\text { montane, rainforest }\end{array}$ \\
\hline D. (Didacus) ciliatus (Loew) & $\begin{array}{c}\text { Anambra, Benue, Nasarawa, Ondo, } \\
\text { Oyo }\end{array}$ & Traps & $\begin{array}{c}\text { Forest savanna, Guinea savanna, } \\
\text { rainforest }\end{array}$ \\
\hline D. transitorius (Collart) & Oyo & Traps & Forest savanna \\
\hline D. umehi sp. n. & Kaduna & Traps & Guinea savanna \\
\hline $\begin{array}{l}\text { Bactrocera (Zeugodacus) } \\
\text { cucurbitae (Coquillett) }\end{array}$ & $\begin{array}{c}\text { Benue, Delta, Edo, Nasarawa, Ogun, } \\
\text { Ondo, Oyo, Plateau }\end{array}$ & Traps, fruits & $\begin{array}{c}\text { Forest savanna, Guinea savanna, } \\
\text { montane, rainforest }\end{array}$ \\
\hline $\begin{array}{l}\text { B. invadens Drew, Tsurata \& } \\
\text { White }\end{array}$ & $\begin{array}{c}\text { Anambra, Benue, Delta, Edo, } \\
\text { Nasarawa, Ogun, Ondo, Oyo, Plateau }\end{array}$ & Traps, fruits & $\begin{array}{c}\text { Forest savanna, Guinea savanna, } \\
\text { montane, rainforest }\end{array}$ \\
\hline $\begin{array}{l}\text { Celidodacus obnubilus } \\
\text { (Karsch) }\end{array}$ & Kaduna & Traps & Guinea savanna \\
\hline Perilampsis woodi (Bezzi) & Kaduna, Oyo & Traps & Forest savanna, Guinea savanna \\
\hline Trirhithrum nigerrimum (Bezzi) & Oyo, Ondo & Traps & Forest savanna, rainforest \\
\hline
\end{tabular}

\subsection{Statistical analysis}

Data on the number of economically important fruit fly species were collated for each of the two types of traps per site (since they cause similar damage). The mean number of fruit flies per trap in each of the states was calculated. Correlation and regression analyses were conducted between the number of fruit flies observed in the traps and assessed damage parameters such as rate of removal of dropped fruits and level of fruit ripening before harvest. All statistical tests were judged significant at $P=0.05$.

\section{Results}

Fruit flies caught in the two types of trap, namely the McPhail ${ }^{\circledR}$ trap and the yellow sticky trap, belonged to the genera Ceratitis, Bactrocera and Dacus (table I). Ceratitis (Pardalaspis) ditissima (Munro) and C.capitata (Wied.) were captured both in
McPhail ${ }^{\circledR}$ traps with yeast hydrolysate bait and yellow sticky traps, and harvested in the laboratory from orange fruit cultures. The latter was observed in many sites in the southern part of Nigeria. Ceratitis (Pterandrus) penicillata (Bigot) was also trapped on citrus during the survey, but it was not observed among fruit flies that emerged from fruit cultures. Other genera of fruit flies observed in trap catches and some of the fruit cultures included Dacus and Bactrocera (table I). Dacus bivittatus (Bigot) was the most predominant species of all the species observed in the traps in various sites. Dacus (Didacus) ciliatus (Loew) was also observed in trap catches in some sites but was not observed in species that emerged from fruit cultures. The first record of D. transitorius (Collart) in Nigeria was established from the trap catches made in two sites in Oyo state. However, adults of this species were not obtained from infested fruits that were cultured in the laboratory. A new species, Dacus umehi sp. n., was 
Table II.

Fruit fly populations observed, in 2003 and 2006, in traps during citrus surveys in eleven states of Nigeria.

\begin{tabular}{|c|c|c|c|c|c|c|c|}
\hline \multirow[t]{3}{*}{$\begin{array}{l}\text { Surveyed states } \\
\text { of Nigeria }\end{array}$} & \multicolumn{4}{|c|}{$\begin{array}{l}\text { Mean number of fruit flies }( \pm S E) \\
\text { per trap and per site }\end{array}$} & \multicolumn{2}{|c|}{$\begin{array}{l}\text { Mean number of fruit } \\
\text { flies per site }\end{array}$} & \multirow[t]{3}{*}{ Observed fruit fly species } \\
\hline & \multicolumn{2}{|c|}{ Sticky trap } & \multicolumn{2}{|c|}{ McPhail $^{\circledR}$ trap } & \multirow[b]{2}{*}{2003} & \multirow[b]{2}{*}{2006} & \\
\hline & 2003 & 2006 & 2003 & 2006 & & & \\
\hline Anambra & $2 \pm 0.30$ & $1 \pm 0.10$ & $5 \pm 0.90$ & $3 \pm 0.80$ & 7 & 4 & $\begin{array}{l}\text { Ceratitis capitata, Bactrocera } \\
\text { invadens, Dacus bivittatus }\end{array}$ \\
\hline Benue & $5 \pm 0.40$ & $3 \pm 0.10$ & $21 \pm 3.00$ & $17 \pm 1.70$ & 26 & 20 & $\begin{array}{c}\text { C. capitata, B. cucurbitae, } \\
\text { B. invadens }\end{array}$ \\
\hline Delta & $4 \pm 0.70$ & $3 \pm 0.30$ & $12 \pm 2.20$ & $9 \pm 1.00$ & 16 & 12 & C. ditissima, B. invadens \\
\hline Edo & $3 \pm 0.30$ & $2 \pm 030$ & $8 \pm 1.30$ & $6 \pm 0.90$ & 11 & 8 & $\begin{array}{c}\text { C. ditissima, B. cucurbitae, } \\
\text { B. invadens }\end{array}$ \\
\hline Imo & $4 \pm 0.50$ & $2 \pm 0.40$ & $8 \pm 1.30$ & $6 \pm 1.20$ & 12 & 8 & C. ditissima \\
\hline Kaduna & $7 \pm 1.00$ & $4 \pm 0.79$ & $32 \pm 9.20$ & $22 \pm 5.70$ & 39 & 26 & C. ditissima, B. cucurbitae \\
\hline Nasarawa & $4 \pm 1.10$ & $2 \pm 0.60$ & $14 \pm 4.50$ & $9 \pm 2.90$ & 18 & 11 & $\begin{array}{l}\text { C. capitata, B. cucurbitae, } \\
\text { B. invadens, D. bivittatus }\end{array}$ \\
\hline Ogun & $3 \pm 0.80$ & $2 \pm 0.50$ & $13 \pm 3.00$ & $8 \pm 1.50$ & 16 & 10 & C. capitata, B. invadens \\
\hline Ondo & $4 \pm 0.80$ & $2 \pm 0.50$ & $14 \pm 6.00$ & $9 \pm 2.20$ & 18 & 11 & $\begin{array}{c}\text { C. ditissima, B. cucurbitae, } \\
\text { B. invadens }\end{array}$ \\
\hline Oyo & $4 \pm 0.50$ & $2 \pm 0.30$ & $20 \pm 6.40$ & $12 \pm 2.80$ & 24 & 14 & $\begin{array}{l}\text { C. ditissima, B. cucurbitae, } \\
\text { B. invadens, D. bivittatus }\end{array}$ \\
\hline Plateau & $2 \pm 0.30$ & $2 \pm 0.20$ & $7 \pm 1.50$ & $5 \pm 0.50$ & 9 & 7 & $\begin{array}{c}\text { C. ditissima, B. cucurbitae, } \\
\text { B. invadens }\end{array}$ \\
\hline
\end{tabular}

identified in specimens collected from Kaduna state during the 2003 survey. The species seems to be rare in occurrence since not more than eight individuals (three female and five males) were collected. Bactrocera (Zeugodacus) cucurbitae (Coquillett) was trapped on sweet oranges and was also harvested from fruits collected from samples taken in most of the surveyed areas. A new species, B. invadens Drew, Tsurata and White, was confirmed both from trap catches and adult flies emerging from sweet orange fruit cultures. The species was observed in the surveys of 2003 but appeared to have spread to many areas in recent surveys. It was not observed in Anambra, Benue, Nasarawa and Plateau states in 2003, but was captured in all the states in 2006. Other species caught in the traps that were presumed not to be of economic importance to sweet orange include Perilampsis woodi (Bezzi), Trirbithrum nigerrimum (Bezzi) and Celidodacus obnubilus (Karsch).

While higher fruit fly species diversity was observed in Edo, Ogun, Ondo and Oyo states in the rainforest ecological zone (table I), relatively higher mean numbers of fruit flies per trap (22 and 17) were, respectively, recorded from each McPhail ${ }^{\circledR}$ trap in 2003 and 2006 in Kaduna and Benue states, in the Guinea savanna ecological zone (table II). A significantly higher $(P<0.001)$ mean number of flies per trap was observed in the McPhail ${ }^{\circledR}$ trap compared with the yellow sticky trap in all surveyed areas. Regression analyses on the relationship between the number of fruit flies (C. capitata, $C$. ditissima, D. bivittatus, B. cucurbitae and B. invadens) caught in traps in 2003 and 2006, and the damage parameters assessed, respectively, showed that fruit fly number was positively correlated with the percentage of attacked fruits $\left(r^{2}=0.49\right.$ and $r^{2}=0.47$; 


\begin{tabular}{|c|c|c|c|c|c|c|}
\hline \multirow[t]{2}{*}{$\begin{array}{l}\text { Surveyed states } \\
\text { of Nigeria }\end{array}$} & \multicolumn{2}{|c|}{$\begin{array}{l}\text { Mean \% of attacked } \\
\text { fruits per site }\end{array}$} & \multicolumn{2}{|c|}{$\begin{array}{l}\text { Rated mean } \\
\text { fruit drop }{ }^{1}\end{array}$} & \multicolumn{2}{|c|}{$\begin{array}{l}\text { Rated range of fruit } \\
\text { ripeness } \\
\text { before harvest }{ }^{2}\end{array}$} \\
\hline & 2003 & 2006 & 2003 & 2006 & 2003 & 2006 \\
\hline Anambra & 11.0 & 8.6 & 1.0 & 1.0 & $1-2$ & $0-1$ \\
\hline Benue & 29.0 & 17.0 & 2.6 & 1.6 & $2-3$ & $1-3$ \\
\hline Delta & 14.0 & 11.0 & 1.2 & 1.6 & $2-3$ & $2-3$ \\
\hline Edo & 12.6 & 8.4 & 1.4 & 1.0 & $1-3$ & $1-3$ \\
\hline Imo & 20.2 & 11.2 & 1.6 & 1.2 & $2-3$ & $2-3$ \\
\hline Kaduna & 30.0 & 16.0 & 2.2 & 1.2 & $1-4$ & $2-4$ \\
\hline Nasarawa & 20.0 & 11.0 & 2.0 & 1.0 & $1-3$ & $1-3$ \\
\hline Ogun & 21.4 & 14.5 & 1.6 & 1.2 & $1-3$ & $1-3$ \\
\hline Ondo & 27.0 & 14.2 & 2.4 & 1.2 & $2-3$ & $1-3$ \\
\hline Oyo & 23.0 & 14.0 & 2.2 & 1.8 & $2-4$ & $1-4$ \\
\hline Plateau & 6.0 & 4.0 & 1.2 & 1.0 & $1-3$ & $0-2$ \\
\hline \multicolumn{7}{|c|}{$\begin{array}{l}{ }^{1} \text { No fruit drop: } 0 ; 1 \text { to } 10 \text { fruits dropped: } 1 ; 11 \text { to } 20 \text { fruits dropped: } 2 ; 21 \text { to } 30 \\
\text { fruits dropped: } 3 ;>30 \text { fruits dropped: } 4 \text {. }\end{array}$} \\
\hline \multicolumn{7}{|c|}{${ }^{2}<50 \%$ fruits: $1 ; 50 \%$ fruits: $2 ;>50 \%$ to $70 \%$ fruits: $3 ;>70 \%$ fruits: 4} \\
\hline
\end{tabular}

$P<0.001 ; \mathrm{df}=48)$, level of fruit drop $\left(r^{2}=\right.$ 0.33 and $\left.r^{2}=0.29 ; P<0.001 ; \mathrm{df}=48\right)$ and level of ripeness of fruits before harvest $\left(r^{2}=\right.$ 0.257 and $\left.r^{2}=0.48 ; P<0.01 ; \mathrm{df}=48\right)$.

The percentage of attacked fruits per site was higher in Benue, Kaduna, Ondo and Oyo (23\% to $30 \%)$ than in other states ( $4 \%$ to $21 \%$ ) (table III). A relatively higher mean percentage of attacked fruits per site was observed in 2003 compared with 2006. Fruit drop was high in most of the surveyed areas and was rated 1 and 2 . This was particularly higher in 2003 than in 2006, especially in the states where the percentage of fruits attacked by fruit flies was high and the fruits were harvested at an advanced ripening stage (table III).

Farmers' responses to questionnaires administered on cultural practices showed that sweet oranges were monocropped in $68 \%$ of the surveyed farms. In the remaining $32 \%$, citrus was intercropped with other vulnerable fruit crops such as mango (Mangifera indica L.), guava (Psidum guajava L.), cocoa (Theobroma cacao L.), kola [Cola acuminata (P. Beauv.)], star apple (Chrysophyllum albidum G. Don) and hog plum (Spondias mombin L.). All farmers recognized damage caused by fruit flies but only about 30\% of the farmers could detect the presence of fruit fly in a fruit without aid from experts. Fifty-six percent of farmers recognized similar damage on fruits of the other alternative hosts reported above. Only $20 \%$ of the farmers regularly removed fruits that dropped in their orchards, and 10\% removed the dropped fruits occasionally, while $70 \%$ did not remove the fallen fruits. Harvesting was done by $13 \%$ of the farmers when $<50 \%$ of the fruits were ripe. Thirtythree percent of the farmers harvested when $50 \%$ of the fruits were ripe, while $38 \%$ and $16 \%$ of the farmers harvested their fruits when, respectively, $>50 \%$ and $100 \%$ of the fruits were ripe. The practice of late harvesting was most prominent in Oyo and Kaduna states, where more than $70 \%$ of the fruits were ripe before harvesting.

\section{Discussion}

The same fruit fly species were identified both in the 2003 and 2006 surveys. The major fruit fly of citrus in Nigeria has been Ceratitis digiitata (Wiedemann) [8, 9]. In the present study, however, other species of Ceratitis were associated with citrus. These were mainly Ceratitis (Pardalaspis) ditissima (Munro), found to be widely distributed in many sites in the southern part of Nigeria; while C. (Pterandrus) penicillata (Bigot), a cola-infesting species in West Africa [11], was also trapped on citrus during the survey. The presence of Dacus bivittatus (Bigot) dominated that of all other species belonging to the same genus.

This species Dacus bivittatus (Bigot) had already been recorded on cucurbits in Nigeria [12]. Although there have been records of non-cucurbit hosts already reported [13], none has been reported on citrus in the surveyed areas. The occurrence of other Dacus species such as Dacus (Didacus) ciliatus (Loew) and D. transitorius (Collart) on citrus was rare. These species have never been associated with sweet 
oranges. However, these results marked the first record of $D$. transitorius (Collart) in Nigeria. The absence of D. ciliatus and D. transitorius among adult species that emerged from fruits indicated that they may not be pests of sweet oranges. Similarly, the newly described species, Dacus umehi sp. n., collected from Kaduna state was not observed among adult fruit flies that emerged from citrus fruits. Bactrocera (Zeugodacus) cucurbitae (Coquillett) was trapped on sweet oranges and was also harvested from fruits collected in most of the surveyed areas. This is probably the first reported occurrence in Nigeria. According to Cogan and Munro [14], B. cucurbita is presumed to be adventive to Africa. Our present survey indicates that it is spreading in Nigeria and may become an important pest of citrus. The occurrence of $B$. invadens, which was confirmed from trap catches and from adult flies emerging from sweet orange fruits cultured in the laboratory, is new in Nigeria. Past surveys conducted in citrus-producing areas did not indicate its presence [15]. It is believed to have been introduced into Africa from the Asian continent [3, 16] and has since spread to many hosts due to its polyphagous nature.

The higher fruit fly species diversity observed in the rainforest ecology compared with the savanna was probably related to the higher floral diversity obtained in the ecology which allows more species to find preferred hosts compared with the savanna. The relatively higher mean numbers of fruit flies per trap recorded in Kaduna and Benue states in the Guinea savanna ecological zone may be due to the presence of large orchards of sweet oranges and mangos with little or no sanitation practices to reduce fruit fly populations in these areas. Consequently, the percentage of fruits attacked by fruit flies on citrus trees and the level of fruits that dropped beneath them were comparatively higher in Kaduna and Benue states than in any other state visited, except in Ondo state. The positive relationships observed between the number of economically important fruit flies and the percentage of attacked fruits, level of fruit drop and level of ripeness of fruits before harvest showed the adverse effect of neglecting citrus cultural practices on the level of fruit fly damage. This implies that, with the absence of any control measure and the continuous increase in the population of fruit flies, the citrus industry could be considerably jeopardized. Two fruiting seasons are usually observed per year in Nigeria. The late fruiting period with fruit maturity occurring in November to January usually produces larger yields than the early fruiting season whereby fruits mature from June to August. Our observation on the reduced number of attacked fruits in 2006 compared with 2003 may therefore be attributed to the maturity period of November to January during which the 2003 study was conducted. The higher availability of fruits in 2003 may have provided enough breeding sites for increased fruit fly population and hence more attacked fruits.

In our study, fruit flies which did not emerge from sweet orange fruit cultures but were only caught in traps hung on sweet orange trees may have been attracted from other intercrop plant hosts or plant hosts in neighboring farms. However, fruit flies recovered from fruit cultures may be serious or potential sweet orange pests that require control interventions. There are reports associating some of the fruit flies identified on citrus in the present study with the attack of the intercrop species observed during the survey $[6,10]$.

Our study showed that some fruit fly species such as C. capitata, D. bivittatus, $B$. cucurbitae and B. invadens are more spread than other identified species in the surveyed areas. The two traps used were found to be efficient at catching various species of fruit flies, although the McPhail ${ }^{\circledR}$ trap baited with yeast hydrolysate caught a higher number of fruit flies than the yellow sticky trap with ammonium acetate. The McPhail $^{\circledR}$ trap with protein hydrolysate bait is therefore preferable in population studies or in mass trapping as a form of control. The yellow sticky trap is ideal for use in early detection of fruit fly attack prior to making decisions on the application of control measures. 


\section{Acknowledgements}

We are grateful to the West African Insect Identification network (WAFRINET) at the IITA, Cotonou in Benin, and Drs. Ian White and $\mathrm{R}$. Wharton for helping with the identification of some fruit fly samples. We are also grateful to the USAID for providing some experimental materials. We thank the Winrock Foundation for facilitating links with fruit fly experts. We also thank the National Horticultural Research Institute for providing funds used in executing the project.

\section{References}

[1] Kapoor V.C., Fruit fly pests and their present status in India, in: Barnes B.N. (Ed.), in: Proc. 6th Int. Fruit Fly Symp., 6-10 May 2002, Stellenbosch, South Africa, 2002, 23-33.

[2] Lux S.A., Zenz N., Kimani S., Economic role and distribution of fruit flies, ICIPE Annu. Rep. 1998/99, Icipe Sci. Press, Nairobi, Kenya, 1999.

[3] Drew R.A.I., Tsuruta K., White I.M., A new species of pest fruit fly (Diptera: Tephritidae: Dacinae) from Sri Lanka and Africa, Afr. Entomol. 13 (1) (2005) 149-154.

[4] Vayssières J.-F., Goergen G., Lokossou O., Dossa P., Akponon C., A new Bactrocera species in Benin among mango fruit fly (Diptera: Tephritidae) species, Fruits 60 (6) (2005) 371-377.

[5] Aiyelagbe I.O.O, Kintomo A.A., Alasiri K.O., Oyedele O.M.O., Adetunji J.A., Giginyu M.B., Afolayan S.O., Olufolaji A.O., Umeh V.C., Citrus production in Nigeria: a state of the art, Res. Monogr. No. 1, NIHORT, Ibadan, Nigeria, 1999.

[6] Umeh V.C., Fatokun H.K., Onukwu D., Insect pests associated with the damage of Chrysophylum albidum G. Don fruits - A case study of Ibadan and its environs, in: Umeh V.C. and
Fagbayide J.A. (Eds.), Proc. 20th Annu. Conf. Hortic. Soc. Niger. (HORTSON), May 14-17 2002, Natl. Hortic. Res. Inst. Audit. Idi-Ishin, Jericho Reservation Area, Ibadan, Nigeria, 2002, $257 \mathrm{p}$.

[7] Agunloye O.O., Trapping and chemical control of Ceratitis capitata (Wied.) (Diptera: Tephritidae) on sweet orange (Citrus sinensis) in Nigeria, J. Hortic. Sci. 62 (2) (1987) 269-271.

[8] Umeh V.C., Ahonsi S., Kolade J.A., Insect pests encountered in a citrus orchard in Nigeria, Fruits 53 (1998) 397-408.

[9] Umeh V.C., Olaniyan A.A., Ker J., Andir J., Development of fruit fly control strategies for small-holders in Nigeria, Fruits 59 (2004) 265-274.

[10] White I.M., Elson-Harris M.M., Fruit flies of economic significance: their identification and bionomics, CAB Int., Wallingford, UK, 1992, $601 \mathrm{p}$.

[11] Entwistle P.F., Pests of cocoa, Longman, London, Rev. Agric. Entomol. 62 (1972) 651.

[12] Matanmi B.A., The biology of Tephritid fruit flies (Diptera, Tephritidae) of cucurbits at lleIfe, Nigeria, Niger. J. Entomol. 1 (1975) 153159.

[13] Munro H.K., A taxonomic treatise on the Dacinae (Diptera: Tephritidae) of Africa, Entomol. Mem., Dep. Agric. Water Supply, Rep. S. Afr. 61 (1984) IX 1-313.

[14] Cogan B.H., Munro H.K., Family Tephritidae, in: Crosskey R.W. (Ed.), Catalogue of the Diptera of the Afrotropical region, Br. Mus. (Nat. Hist.), London, UK, 1980, pp. 518-554.

[15] Umeh V.C., Aiyelaagbe I.O.O., Kintomo A.A., Giginyu M.B., Insect pests situation and farmers' cultural practices in citrus orchards in the Southern Guinea savanna agro-ecological zone of Nigeria, Niger. J. Hortic. Sci. 7 (2000) 26-32.

[16] Mwatawala M.W., White I.M., Maerere A.P., Senkondo F.J., De Meyer M., A new invasive Bactrocera species (Diptera: Tephritidae) in Tanzania, Afric. Entomol. 12 (2004) 154-156. 


\begin{abstract}
Las moscas de las frutas en Nigeria: diversidad de las especies, abundancia relativa y extensión en las zonas principales de producción.
\end{abstract}

Resumen - Introducción. El ataque de los cítricos por parte de las moscas de las frutas en Nigeria causa pérdidas de rendimiento con repercusiones económicas. La fuerte demanda de naranjas dulces registrada este último tiempo impone la voluntad de desarrollar estrategias de control capaces de reducir los daños achacables a las moscas de las frutas y a mejorar el rendimiento. Esto puede realizarse mediante la identificación de la diversidad, la abundancia y la difusión de las principales moscas de las frutas de las naranjas dulces. Material y métodos. Se llevaron a cabo prospecciones durante los periodos de madurez de los cítricos en el 2003 y en el 2006, en las zonas de producción de Nigeria. Se interrogó a los dueños de los vergeles muestreados sobre las prácticas culturales que podrían contribuir tanto al crecimiento de las poblaciones de las moscas de las frutas como a su difusión. Se recolectaron las moscas de las frutas gracias a dos tipos de trampas, concretamente la trampa de McPhail ${ }^{\circledR}$ con cebo de hidrolizado de levadura y la trampa pegajosa amarilla empapada de acetato de amonio. Se colgaron las trampas sobre los cítricos a $1.8 \mathrm{~m}$ de altura, a razón de tres trampas por zona. La distancia entre árboles fue de $25 \mathrm{~m}$. Resultados y discusión. Las moscas de las frutas identificadas en los cítricos se relacionaron a los tipos Bactrocera, Ceratitis, Dacus y Trirhithrum. A pesar de que se observó una diversidad más amplia en los estados de Edo, Ogun y Oyo en zona ecológica de bosque tropical, se registraron poblaciones relativamente más importantes de los tipos principales (Bactrocera y Ceratitis) en los estados de Benue y de Kaduna a lo largo del segundo periodo de muestreo. Las prácticas culturales de ciertos agricultores resultaron ser factores probables de contribución a la abundancia y a la difusión de las moscas de las frutas. Conclusión. Las especies de las moscas de la fruta de importancia económica en los cítricos en Nigeria pertenecen a las especies de tipos Ceratitis y Bactrocera. Se identificaron en la mayoría de las regiones prospectadas.

Nigeria / Citrus / insectos depredadores de los frutos / Tephritidae / Ceratitis / Bactrocera / Dacus umehi / identificación / cultivo / trampas 